IRA-International Journal of Management \& Social Sciences

ISSN 2455-2267; Vol.03, Issue 03 (2016)

Institute of Research Advances

http://research-advances.org/index.php/RAJMSS

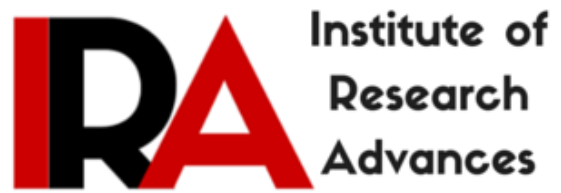

\title{
Begging in India: Barricading the Sustainable Financial Development
}

\author{
${ }^{1}$ Mr. Abhishek Janvier Frederick \\ Assistant Professor, Joseph School of Business Studies, \\ Sam Higginbottom Institute of Agriculture, Technology \& Sciences, Allahabad, India. \\ ${ }^{2}$ Dr. Sebastian .T. Joseph \\ Sr. Assistant Professor, Joseph School of Business Studies, \\ Sam Higginbottom Institute of Agriculture, Technology \& Sciences, Deemed -to be- \\ University, Allahabad, India. \\ ${ }^{3}$ Himanshi Srivastava \\ BBA Student, Joseph School of Business Studies \\ Sam Higginbottom Institute of Agriculture, Technology \& Sciences, Deemed -to be- \\ University, Allahabad, India.
}

DOI: http://dx.doi.org/10.21013/jmss.v3.n3.p4

\section{How to cite this paper:}

Frederick, A., Joseph, D., \& Srivastava, H. (2016). Begging in India: Barricading the Sustainable Financial Development. IRA-International Journal of Management \& Social Sciences (ISSN 2455-2267), 3(3). doi:http://dx.doi.org/10.21013/jmss.v3.n3.p4

(C) Institute of Research Advances

\section{(c)) EY-NC}

This works is licensed under a Creative Commons Attribution-Non Commercial 4.0 International License subject to proper citation to the publication source of the work.

Disclaimer: The scholarly papers as reviewed and published by the Institute of Research Advances (IRA) are the views and opinions of their respective authors and are not the views or opinions of the IRA. The IRA disclaims of any harm or loss caused due to the published content to any party. 


ABSTRACT
India is the most powerful country in terms of economy. The rapid growth in economy
and population is also increases the poverty in the Indian country. This increasing
population is causing disc breaks to the development of economy, with problems such
as supply of food and demand of food, begging is one of them which is affecting the
Indian economic system in a most serious manner as in the human resource is getting
unutilised.
Begging is most serious social issue in India. Begging is a problem for society is as
much as large no. of beggars means not utilization of human resources and available
resources in existing environment. This paper tries to examine the reasons causes of
begging and the awareness of government schemes run for the people of such kind
who are involved in begging at Allahabad.

Keywords: Economy, Begging, Unemployment

JEL Classification; G0,D6

\section{INTRODUCTION}

Begging technically known as "panhandling" defines a situation where in the needy asks for material benefits or money - often even basic amenities like food and clothing ( Nirav Shah, 2011) Begging is one of the most endemic multifaceted social problems with great magnitude, but it is less understood in all its dimensions. (CAMA, 1945) while the begging in India has always been an object of ephemeral attention of charity, the problem of beggary as such has not become a subject for an in-depth scientific inquiry. Though there have been a few works on this poignant

Begging is a social ill whose implications for city economy and environment call for concern of urban planners. The negative impacts of begging on social and physical environments are obvious in the tendency of beggars to delay and obstruct free flow human and vehicular traffic and their high propensity to generate dirty materials either as waste or as parts of their belonging (Jelili 2006 cited by Namwata et al. 2010, 53-60). Adedibu (1989, 25-40) also observed that begging also has implications for the economy of the nation as beggars depend on the already overstretched workforce. Begging has been a serious problem confronting many urban areas across the globe. The situation becomes worse when it confronts urban areas of less developed nations.

The magnitude of the problem is very much poignant in developing countries and particularly in India. Begging as a social event is a problem for the society. The larger the chunk of population involved in begging, the heavier the burden on working population and lesser the usage of human resources for constructive human development. Begging has become the mainstay for a quite large section of the population. Delhi school of social survey (quoted form Azad Foundation ob. cited) reveals that in a decade since, 1991, the number of beggars has gone up by lakh in India. Action Aid Report 2004, (quoted form Azad foundation) divulged that "there are some 60000 beggars in Delhi, over 300000 in Mumbai". The Council of Human Welfare report2005 (quoted form Azad foundation) disclosed that in Hyderabad out of every 354 persons one is found begging.

Most of the studies on this pressing issue concentrated on describing the socioeconomic conditions and causations of begging in urban and semi-urban areas, or on 
the historical and philosophical background of it. Kumarappa (1945) focused on portraying the living conditions of the beggars in Bombay. Tirumalaiah (2004) elicited the place of begging in Tamil literature and religious traditions. He depicted the causes, connotations and situations of begging from the classical Tamil literature, even in the pre-Christian era.

India is a large country in area. It is roughly 2.4 percent of the total area of the world. But do you know what percentage of the world's population it has? Well, it is about 16.7\%. As per Census 2011, India's population is 1210 million. With such a huge population, some economic problems have developed. These are the problems of unemployment, Inflation, poverty and price rise. A large section of our population lives under the poverty line. There is a huge unemployment. Inflation and price rise has added to the problem.

It is a painful experience to come across beggars wherever we go. At the market place, railway station, hospital, temple, even at road crossings, you will notice some people approaching you with open palms. They ask for money or food. We also see many children begging in the streets. Beggary is a major social problem in India. The major causes of beggary in our country are poverty and unemployment. These days many gangs are operating in our society as well, that thrives on begging in an organized manner. However beggary is a social curse which must be eradicated.

\section{RESEARCH OBJECTIVES}

1. To study the causes of begging.

2. To study the schemes run by the government to eradicate problem.

3. To do an in-depth analysis of the study begging in Indian economy.

\section{REVIEW OF LITREATURE}

- (Siddique, 2008) in his article "Begging: A Rs 1.8 billion industry" has stated that the title Beggars in Hyderabad, Rafiuddin says there were 73, 00,000 beggars across India who earn as much as Rs 180 crore (Rs 1.8 billion). The study put the number of beggars in Hyderabad at 11,000 with a total earning of Rs 15 crore (Rs 150 million).

- (Adedibu \& Jelili, 2011) In his article "Package for controlling street begging and rehabilitating beggars and the physically challenged in Nigeria: Paper for policy consideration". Global categories of street beggars and factors influencing street begging.

- (Khan, 2013) Showed in his case study "Regional Analysis of Various Places of Begging": an analyze in this study Most of the beggars preferred to move to the residential areas, markets and religious places of the district. Half of the beggars of the district preferred to go outside their own village or town for begging purpose and the proportion of native places and the other states of India recorded high in the urban areas as compare to the rural areas in which beggars mainly move to the surrounding villages.

- (Reddy, 2013) In her case study "Begging And Its Mosaic Dimensions: Some Preliminary observations In Kadapa District Of Andhra Pradesh" the analyse is that Begging as a profession does encompass people from all the sections, including all age groups, sex, and caste groups. There is no significant difference across the caste groups in terms of number of beggars. Majority of the beggars have resorted to this profession not because of lack of economic resources, but due to some intra-family issues. Around 70 percent of the beggars hail from agriculturally potential areas. Regarding property possession, 74 percent of them 
have one or the other type of own property, and the value of such property shows a wide variation among them. Some have exceptional value of Rs.4000000/- to 5000000 .

- (Khan, Menka, \& Shamshad, 2013) In their study stated that The overall analysis of the data shows that poverty and unemployment are the main problems faced by these people along with others problem i.e. supply of electricity, lack of sanitation, potable water and proper housing, non-availability of ration card, daughter's marriage, various disease, etc. in both rural and urban areas. The newly settled beggars of rural origin have mostly housing and water problems.

- (Khan, Menka, \& Shamshad, 2013) the study is based on primary source of data, collected through the field survey in the Aligarh district carried out during 2009 and altogether, 496 households of beggars were surveyed for the present study from the 70 villages of the district. Spatial analysis reveals the fact that the high level of demographic, literacy, employment, infrastructural facilities among rural beggars is witnessed in the peripheral parts of the district while, high level of per capita income is found in the central part of the study area.

- (Rafiuddin, 2012) in his article "Begging a Rs.200 crore industry in India" he stated that but begging in India is Rs.200 crore industry and this has been said after two year survey by Dr. Rafiuddin, on average a beggar earns Rs.24,000/per month in cities which is almost equal to a white collar job salary. There are instances of rich beggars in India for example a beggar was found with Rs.8,00,000/- in his garbage bag or a beggar with an insurance of Rs.36,000/per year and though there are rich beggars the income is spread unevenly across the country.

- (Cook, 2016) in his article "India Beggars and Begging Scams: What You Should Know" has stated there is often more than meets the eye about begging in India. While the poverty is real, begging is quite often carried out in organized gangs. For the privilege of begging in a certain territory, each beggar must hand over their takings to the gang's ring leader, who keeps a significant share of it. Beggars have also been known to deliberately maim and disfigure themselves to get more money. Quite a bit of welfare work in India has been directed at reducing begging, including provided beggars with jobs, with varying degrees of success. The most common problem is that the beggars are so used to begging that they actually prefer not to work.

\section{Research Methodology}

\section{Description of the study area:}

Allahabad, also known as Prayag is a city in the Indian state of Uttar Pradesh and the administrative headquarters of Allahabad District, the most-populous district in the state. As of 2011, Allahabad is the seventh most-populous city in the state, fifteenth in the Northern India and thirty-sixth in India, with an estimated population of 1.11 million in the city and 1.21 million in its metropolitan region. In 2011 it was ranked the world's 130th fastest-growing city. Allahabad, in 2013, was ranked the third most liveable city in the state (after Noida and Lucknow) and twenty-ninth in the country.

Located in southern Uttar Pradesh, the city's metropolitan area covers $70.5 \mathrm{~km}^{2}$ (27.22 sq miles).Although the city and its surrounding area are governed by several municipalities, a large portion of Allahabad District is governed by the Allahabad City Council. The city is home to colleges, research institutions and central and state government offices. Allahabad has hosted cultural and sporting events, including Kumbh Mela and the Indira Marathon. Although the city's economy was built on tourism, most of its income now derives from real estate and financial services. 


\section{Research Design}

The present study is focused on the exploratory research design.

\section{Data used}

The primary data has been the modus operandi for exploring the causes of begging and awareness of beggars toward the government schemes, the secondary data has been the base on which the study stands.

\section{Data Source}

The primary data for the study has been collected from persons who has been engaged in begging across the city, through personal interview method to know their experience.

\section{Sample population}

In this study the respondents are the beggars which, comes from different age group.

\section{Sample size}

The sample for the study was 100 respondents.

\section{Primary data source}

The primary data for the study was collected from the respondents by personal interview method using pretested schedule. The primary data collected was based on the memory of the respondents.

\section{Sample area}

The study was conducted in Allahabad district of Uttar Pradesh. Allahabad district is sub divided into Allahabad East and Allahabad West according to the local governing body i.e. nagar nigam.

\section{Period of study}

The study had been conducted from commencing from $1^{\text {st }}$ January 2016 to $31^{\text {st }}$ April 2016 and completed in a period of four months.

\section{DATA ANALYSIS}

\section{Q1-Gender}

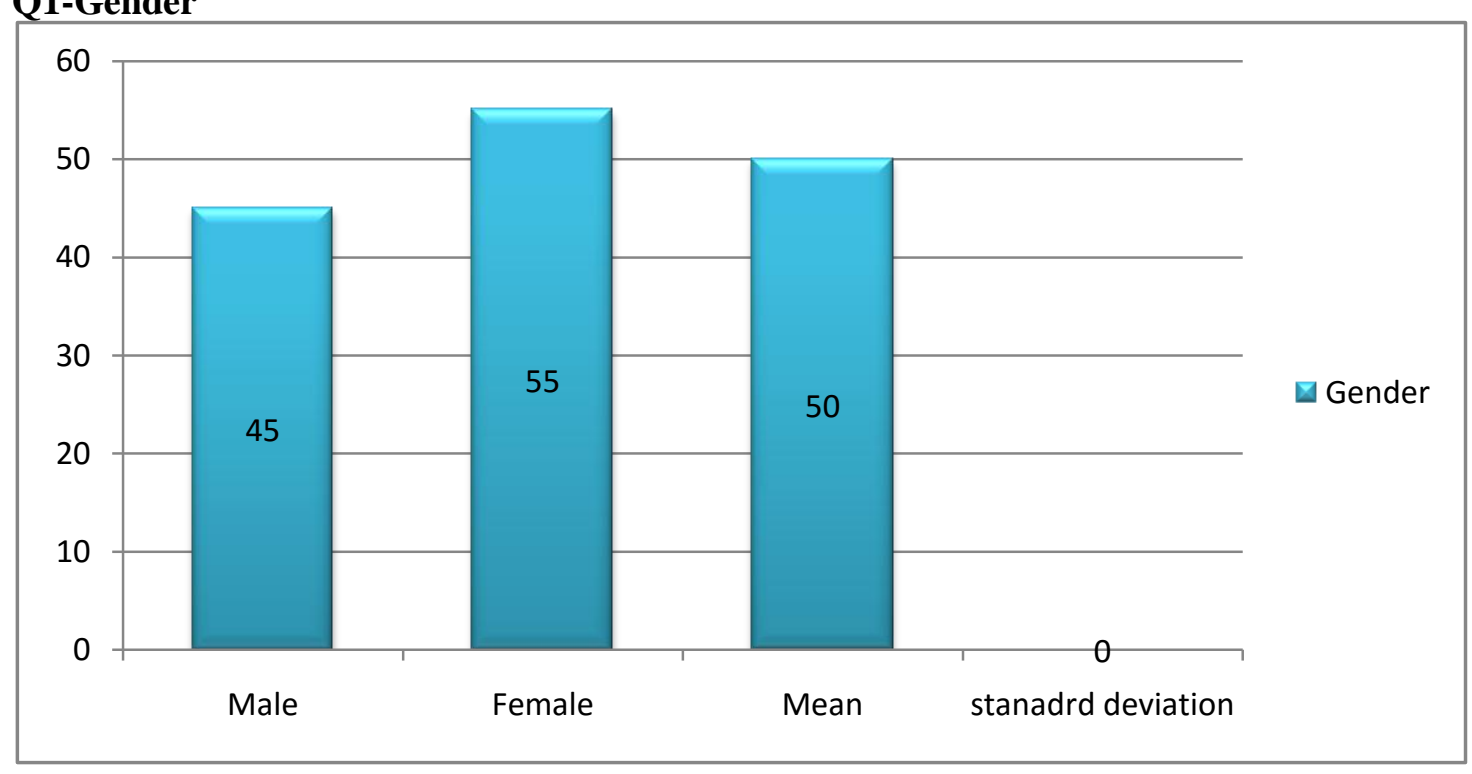

\section{Figure 1.1}

Interpretation: From the above figure 1.1 it represents the data of female beggars are $45 \%$ and male beggars are $50 \%$ and their mean is 50 . Standard deviation is 0 . 


\section{Q2.Age}

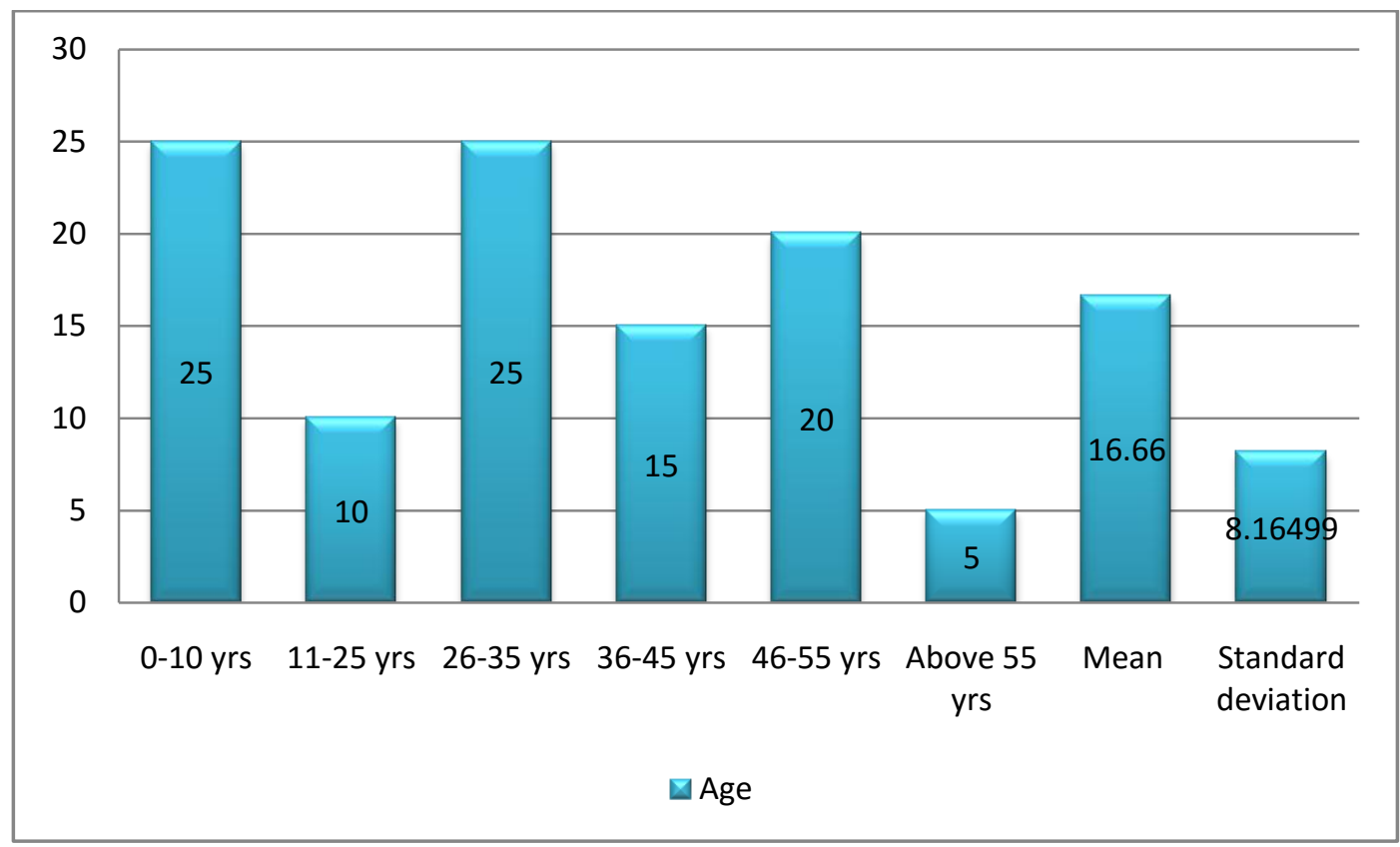

\section{Figure 1.2}

From the above figure1.2 it reveals that the percentage of age group in beggars is less than $25 \mathrm{yrs}$ is $30 \%$ and above the age group of $26 \mathrm{yrs}$ is $65 \%$. Average of the group is 16.66 and standard deviation is 8.16499 .

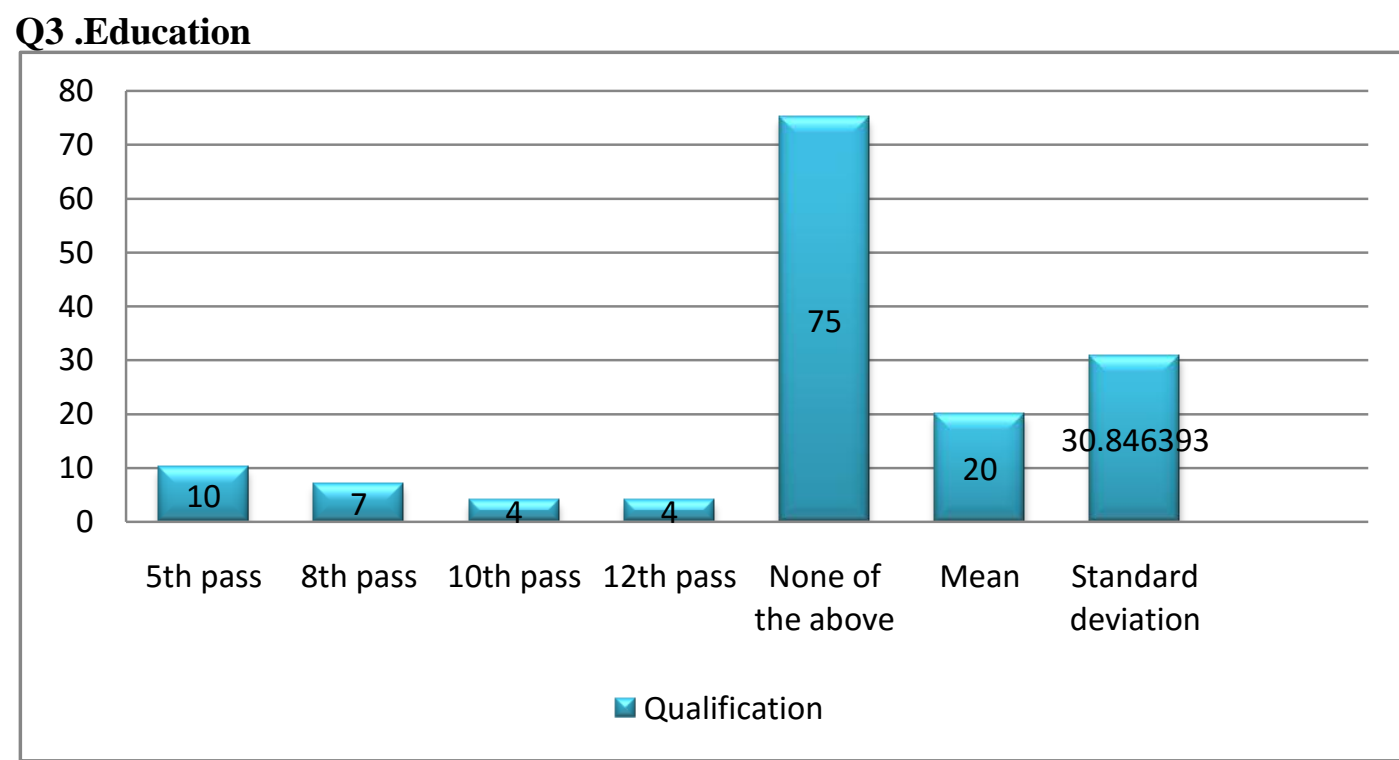

\section{Figure 1.3}

From the above figure 1.3 it represents the data of education of the beggars is very low and the percentages are in $10^{\text {th }}$ is $4 \%, 12^{\text {th }}$ is $4 \%$ and none of the above is $75 \%$. The average of the qualification is 20 and standard deviation is 30.846393 .

\section{Q4- What is main reasons for begging?}

Figure 1.4 (Refer Annexure) represents the data of main reasons of the begging is poverty and unemployment. The percentage of poverty is $55 \%$ and the unemployment 
is $15 \%$, the percentage of large no. of the family is 5\% and death of a parent is $5 \%$. The mean of the reasons of begging is 16.66 and the standard deviation is 19.148514.

\section{Q5- How much you earn in one day?}

As per the figure 1.5 (Refer Annexure) it shows that the earning of the beggars in a day represent as percentage are above Rs 200 is $45 \%$ and lowest earning is Rs.50 is $24 \%$. The mean of earning of the beggars in a day is 33.33 and standard deviation is 10.6926774 .

\section{Q6- Why don't you do a job?}

The figure1.6 (Refer Annexure) it represents the data of why beggars don't do a job and the majority of the beggars not doing a job because of lack of education and the percentage is $40 \%$ and another reasons is due to minor and the percentage is $30 \%$. The mean of the beggars don't do a job is 20 and the standard deviation is 14.21267.

\section{Q7- From where did you get the idea of begging?}

The figure 1.7(Refer Annexure) represents the data of most of the respondents get the idea of begging from the other sources. The percentage of from other sources is $75 \%$ and lowest percentage is friends which is $5 \%$. The mean of the idea of begging is 33.33 and the standard deviation is 36.855574 .

\section{Q8- Do you have a family?}

From the figure 1.8 (Refer Annexure) it reveals that the 95\% of the beggars having family and $10 \%$ of the beggars don't have family. The mean of the family is 55 and standard deviation is 64.031242 .

\section{Q9- If yes, how many members are in your family?}

From the figure 1.9 (Refer Annexure) it represents the data of percentage of members in family of beggars. The highest percentage is 5 members in a family is $32 \%$ and lowest percentage is 4 members in a family is $18 \%$. The mean of the family members is 23.75 and the standard deviation is 6.2382242 .

\section{Q10- What mode of alms do you get?}

The Figure 1.10 (Refer Annexure) represents the data of mode of payment of beggars. The $65 \%$ of beggars get the both money and food and $35 \%$ of beggars get the money. The mean of the mode of payment is 55 and standard deviation is 22.3606797 .

\section{Q11- How do you spend your money?}

The Figure 1.11 (Refer Annexure) it represents the data of spending money by beggars. $45 \%$ of the beggars spend their money on food, $5 \%$ of beggars spend their money on drinking alcohol. The mean of the spend money is 17.5 and the standard deviation.

\section{Q12- Are you aware about government services?}

The Figure 1.12 (Refer Annexure) it represents the data of awareness about the government services. $90 \%$ of the beggars are unaware about the government services and $10 \%$ of the beggars are known about the government services. The mean of the awareness about the government services is 55 and the standard deviation is 57.008 . 


\section{Q13- If yes, then do you avail any services from government?}

The Figure 1.13 (Refer Annexure) represents the data of get the any service from government. $6 \%$ of the beggar's het the service from government and the $4 \%$ of the beggars are not get the any service from government. The mean of the get any service from government is 5 and the standard deviation is 1.4142 .

\section{Q14- If yes, which of the following services you have availed?}

The Figure 1.13(Refer Annexure) only 6\% beggars get the service from government and from figure 1.14 represents the following services of the government. $3 \%$ of the beggars get the ration card service and $1 \%$ of the beggars get the BPL card service. The mean of the following services is 1.2 and standard deviation is .09899.

\section{Q15- Are you satisfied with the schemes received by government?}

The Figure 1.15 (Refer Annexure) represents the data of satisfied with the help received by government. $2 \%$ of the beggars are satisfied with the help received by the government and $4 \%$ of the beggars are not satisfied with the help received by government. The mean of the satisfaction of beggars are 3 and the standard deviation is 1.4142 .

\section{Q16- If yes, then which or what scheme you have got?}

The Figure 1.16 (Refer Annexure) represents the data of service which they got. Only $2 \%$ of the beggars get the help of ration card. The mean of the help which they got is 2 and the standard deviation.

\section{FINDINGS}

The result derived from the research study shows that $10 \%$ female beggars are more than male beggars.

1- The result derived from research study shows that the $65 \%$ beggars are above 25 yrs.

2- In this study the result has come that $45 \%$ of respondents earn above Rs. 200 in a day and they don't do a job because of lack of education.

3- According to analysis $30 \%$ of the respondents are minor.

4- The result has derived from the research study $95 \%$ of the respondents have their families.

5- In this study the result has come that $65 \%$ of respondents get the money and food both from the public.

6- The result has derived from the study $90 \%$ of the respondents' are unaware from the services provided by the government to the poor. Very less no. of respondents get the benefit from services.

7- Few of the respondents are satisfied with services provided by the government.

8- The main reasons of begging are the poverty and unemployment.

This study reveals that the government take steps to eradicate poverty and unemployment, with the help of different schemes for uplifting the social status of beggars, but the outcomes are not up to the expectations of the government.

A) Pradhan Mantri Jan DhanYojna (PMJDY): Covering accidental insurance covering amounting to Rs.1 lakh.Life insurance worth Rs.30000.

B) Pradhan MantriSuraksha Bima Yojna(PMSBY): this scheme provide to the age grpoup of 18-70 yrs. Provided life cover amounting to Rs.2 lakh. 1 lakh for disability in accident. 


\section{C) Agriculture schemes}

(a) KisanVikas Patra: Farmer can invest in this programme in the domination of Rs. 1000, 10000, 5000 and get doubled after 100 month. It can be used as a collateral to get loans and accountholders get an interest of $8.7 \%$

\section{D) Rural scheme}

(b) Prandhan Mantri Gram Sicchai Yojna: attempta to provide water for irrigation of different part of the country.

Pradhan Mnatri Sansad Adarsh Gram Yojna: Places the responsibility of rural development on the MPs. 3 villages at 2016. It is expected that by 2024, 6433 adarsh gram will be created.

E) Mahatma Gandhi National Rural Employment Guarantee ACT (MGNREGA) in which 100 days of work are guaranteed to people in villages across the country.

F) Integrated Rural Development Programme (IRDP) this the programme looks to provide assets, generated by the dint of income, to the poorest people in India.

G) Annapurna programme is launched provide food the senior citizens who cannot take care of themselves and are not under the National Old Age Pension Scheme. This scheme would provide $10 \mathrm{~kg}$ of free food grains a month for the eligible.

\section{CONCLUSION}

1. The conclusion of this study is that the female beggars are more than the male beggars.

2. Most of the respondents have their families and each member of their family are engaged in begging.

3. The conclusion of this study is that most of the respondents are don't have any identity proof.

4. According to survey an average income of each respondent is Rs.200 per day which is around Rs.2lakh per annum.

5. Survey shows that by the begging respondents earn in a lakhs of rupees which is not contributing to our economy and indirectly effect to our country.

6. Majority of the respondents are major but they don't want to do work as they get easy money without any effort by begging.

\section{RECOMMENDATIONS}

1- Provide knowledge by doing camping.

2- Provide facility that they easily get ration card and BPL card.

3- Making people aware and motivating them for earning by doing work.

4- Don't promote begging.

5- Provide information about financial instrument products.

\section{REFRENCES}

Adedibu, A. A., \& Jelili, M. O. (2011). Package for controlling street begging and rehabilitating beggars and the physically challenged in Nigeria: Paper for policy consideration. Global Journal of Human Social Science, 11(1).

CAMA, K. H. (1945). TYPES OF BEGGARS . In D. J. KUMARAPPA (Ed.), OUR BEGGAR PROBLEM HOW TO TACKLE IT (pp. 1-11). BOMBAY: FADMA PUBLICATIONS LTD . 
Cook, S. (2016, January 24). India Beggars and Begging Scams: What You Should Know. Retrieved from goindia.about.com:

http://goindia.about.com/od/annoyancesinconveniences/p/indiabegging.htm

Khan, J. (2013). Regional Analysis Of Various Places Of Begging. International Journal of Development Research, 3(10).

Khan, J. H., Menka, \& Shamshad. (2013). Beggars in rural areas: A socio-economic analysis. IOSR Journal of Humanities and Social Sciences, 122-129.

Khan, J. H., Menka, \& Shamshad. (2013). Problems of Beggars: A Case Study. nternational Journal of Management and, 2(12), 67-74.

Nirav Shah. (2011, November 8). Beggary In India: Generously Putting Stop To It. Retrieved from www.youthkiawaaz.com: http://www.youthkiawaaz.com/2011/11/beggary-in-india-generously-puttingstop-to-it/

Rafiuddin, D. (2012). Begging a Rs.200 crore industry in India . Retrieved from http://rottenview.blogspot.in: http://rottenview.blogspot.in/2012/04/beggingrs200-crore-industry-in-india.html

Reddy, C. (2013). Begging And Its Mosaic Dimensions: Some Preliminary Observations In Kadapa District Of Andhra Pradesh. Afro Asian Journal of Social Sciences, 4(1).

Shah, N. (2011). Begging In India:Generously Putting Stop To It.

Siddique, M. (2008, Oct 10). Begging: A Rs 1.8 billion industry. Retrieved from http://www.rediff.com: http://www.rediff.com/money/2008/oct/10beg.htm 
Annexure

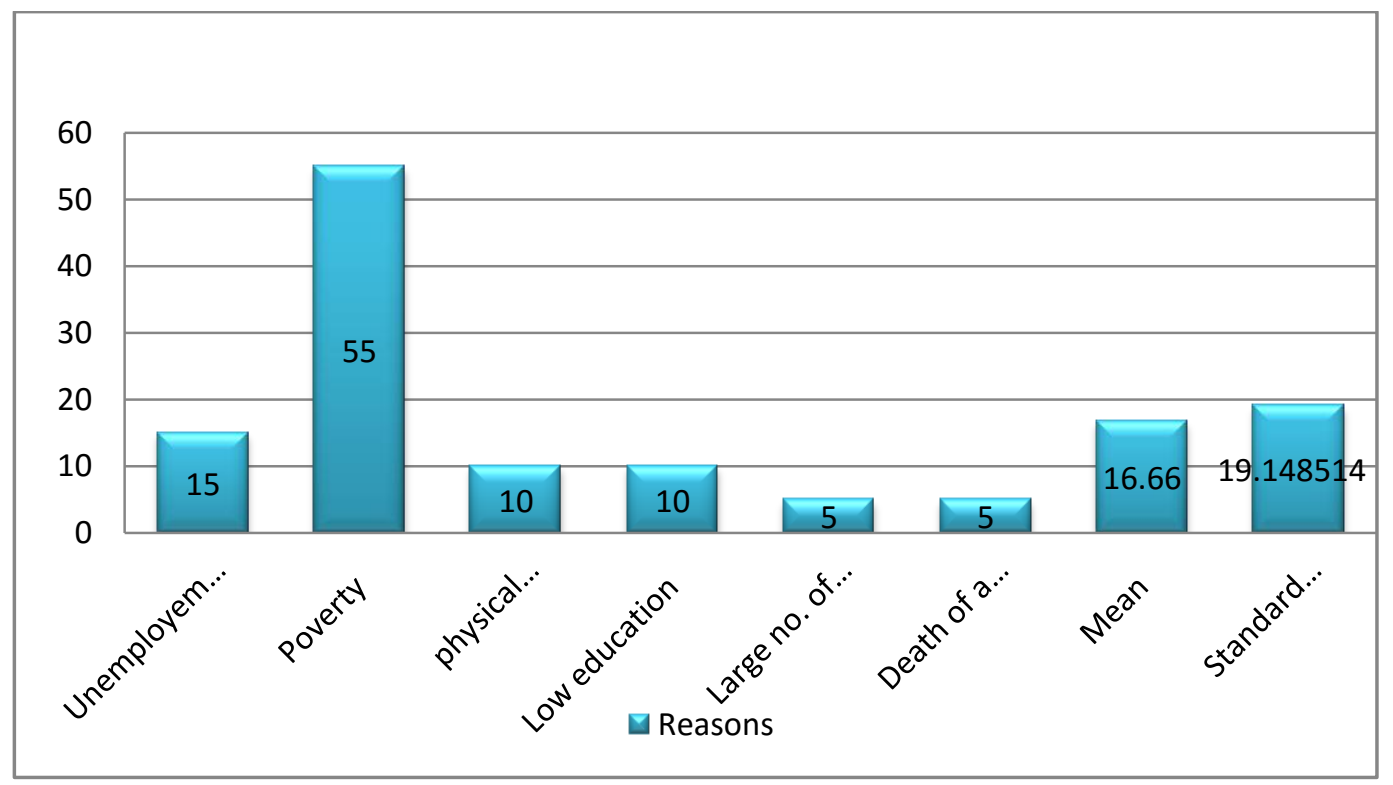

Figure 1.4 Reasons for begging

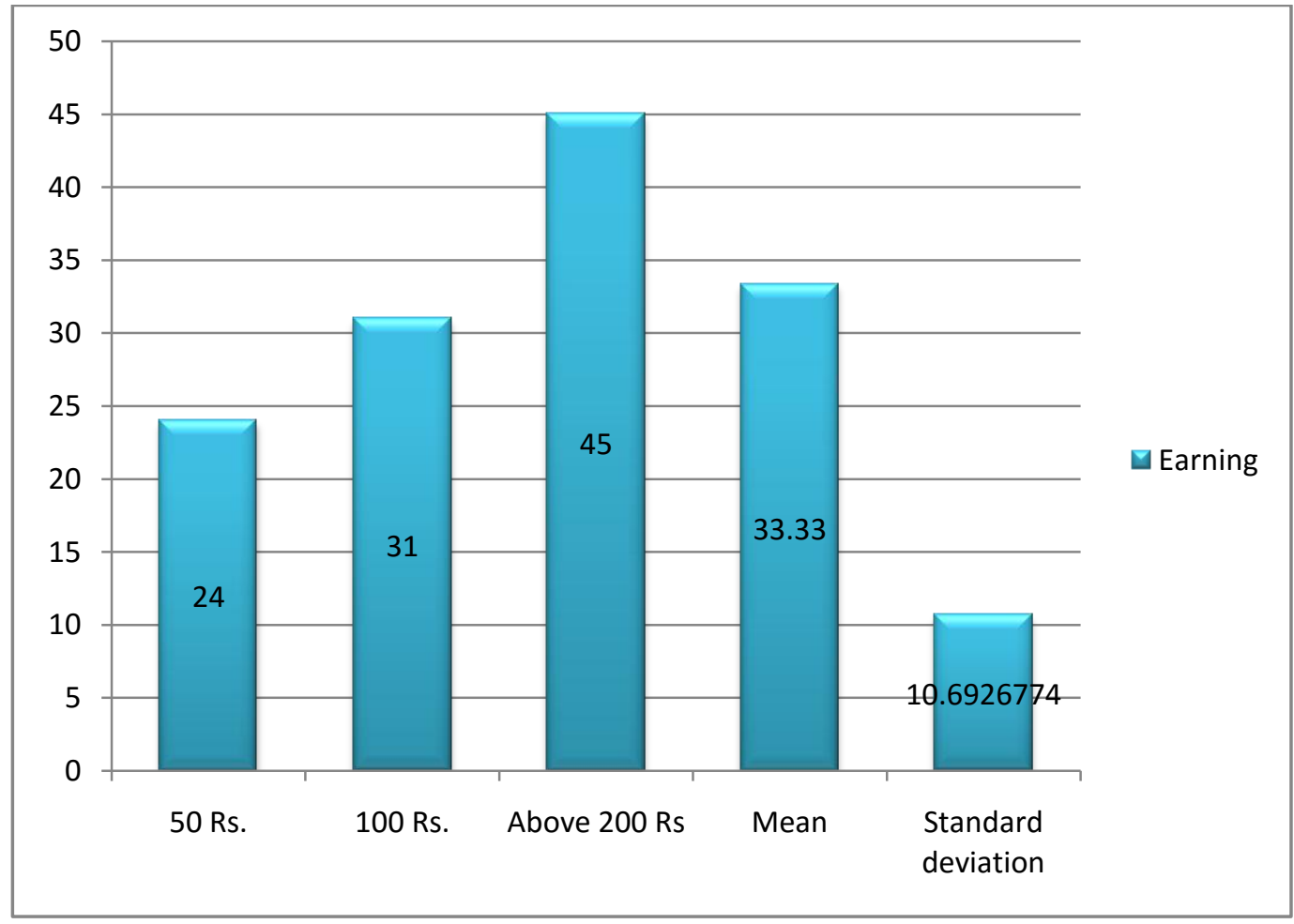

Figure 1.5 Earnings Per Day 


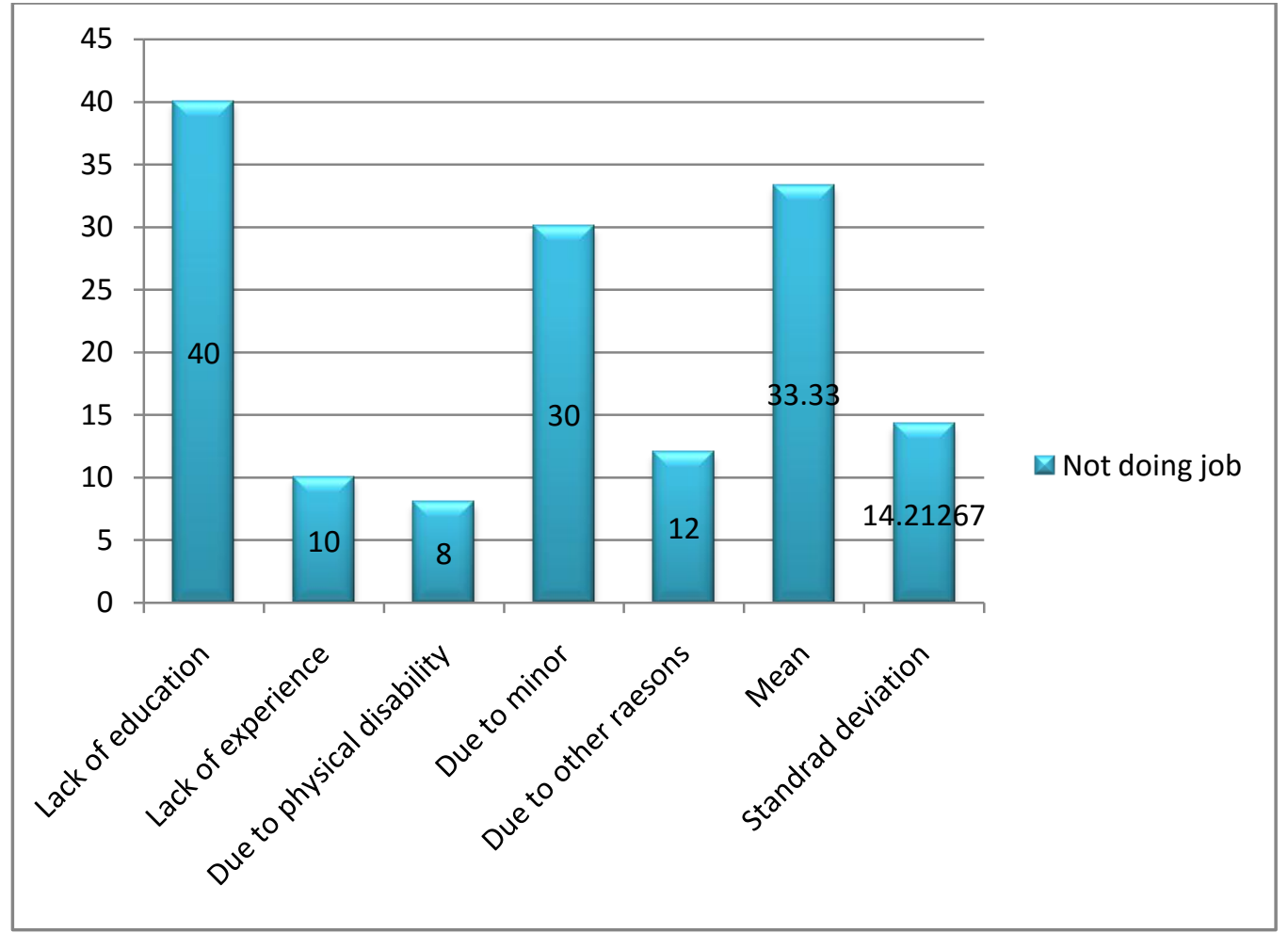

Figure 1.6 Causes Of Not Doing Job.

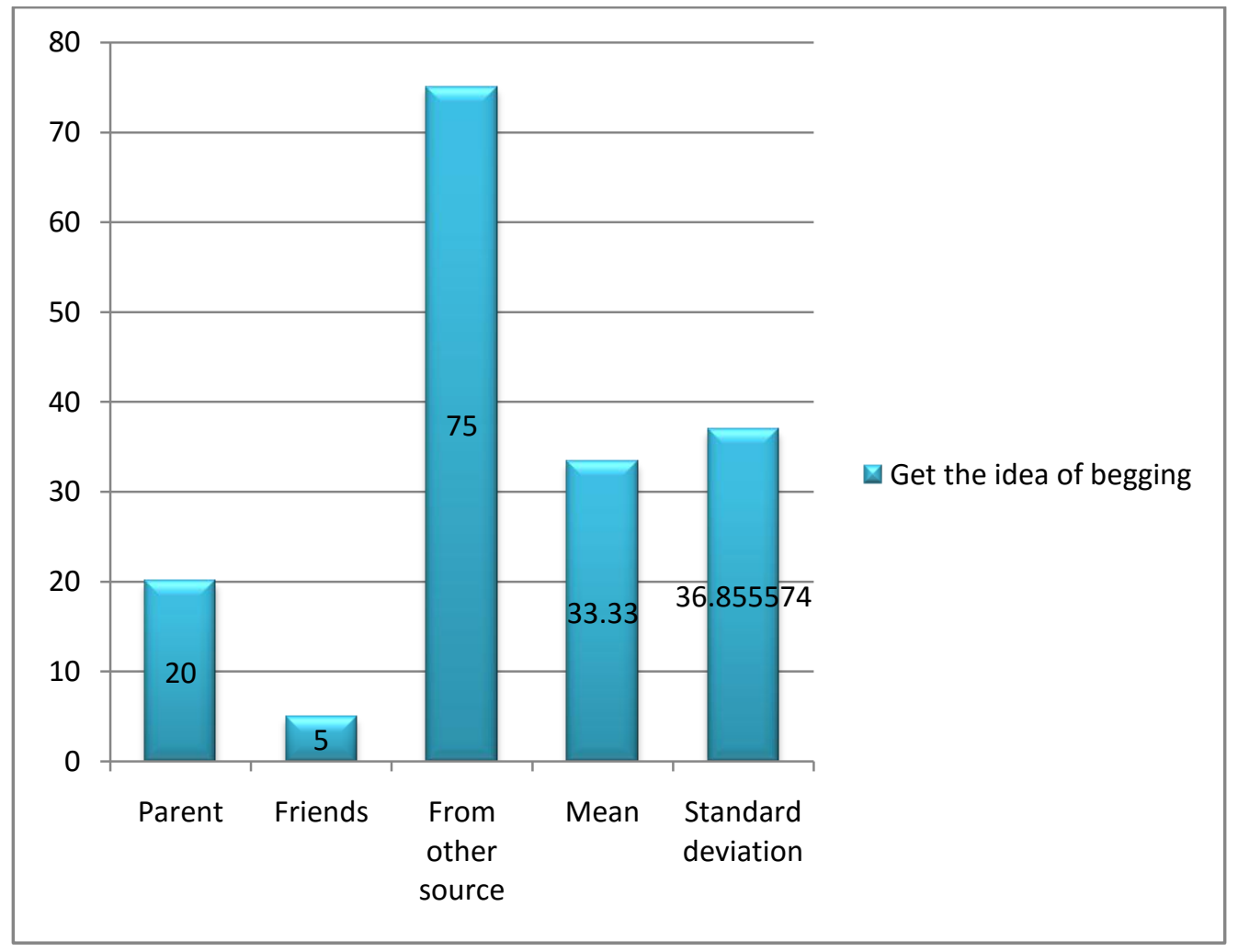

Figure 1.7 Motivation Towards Begging 


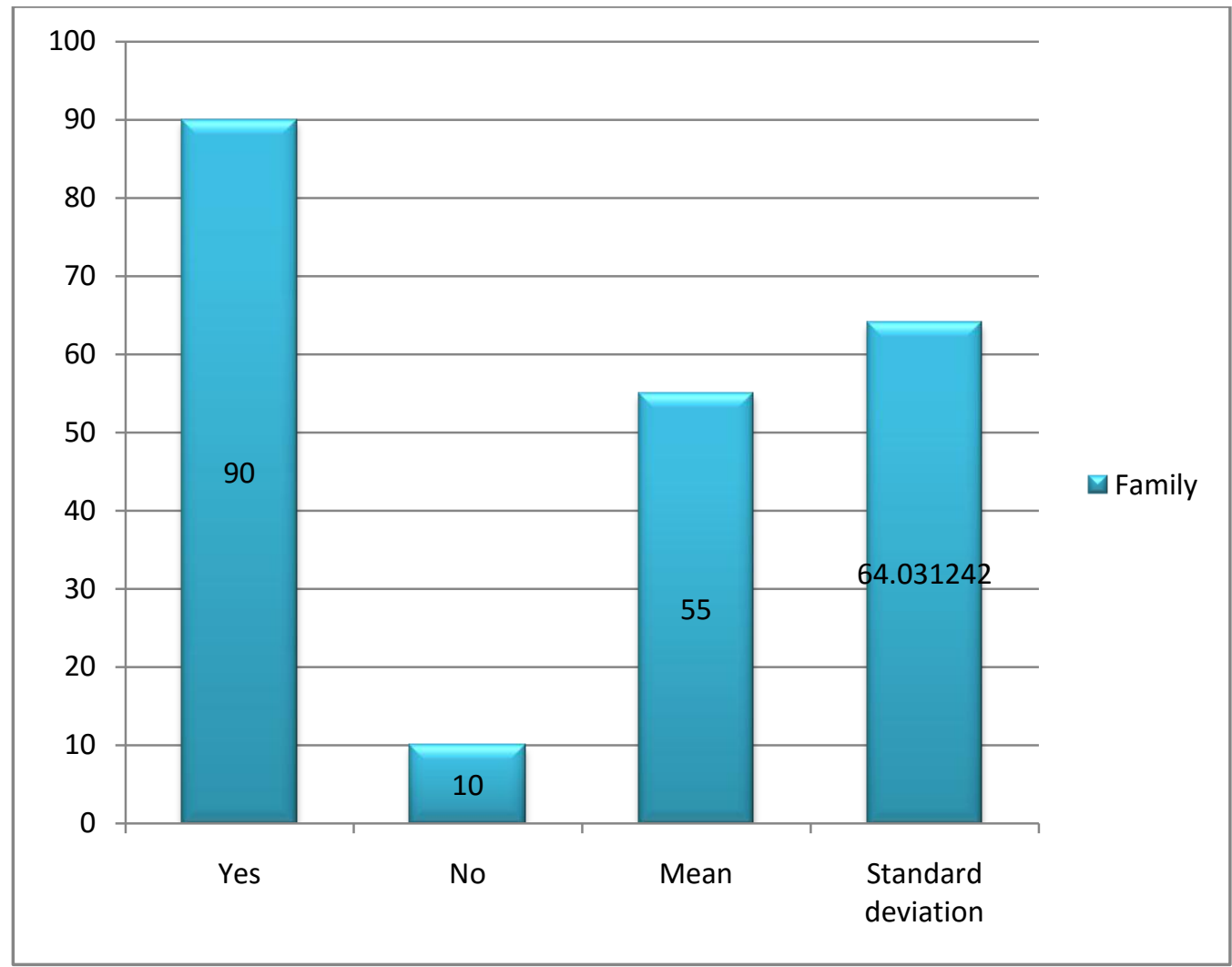

Figure 1.8 Family /Single

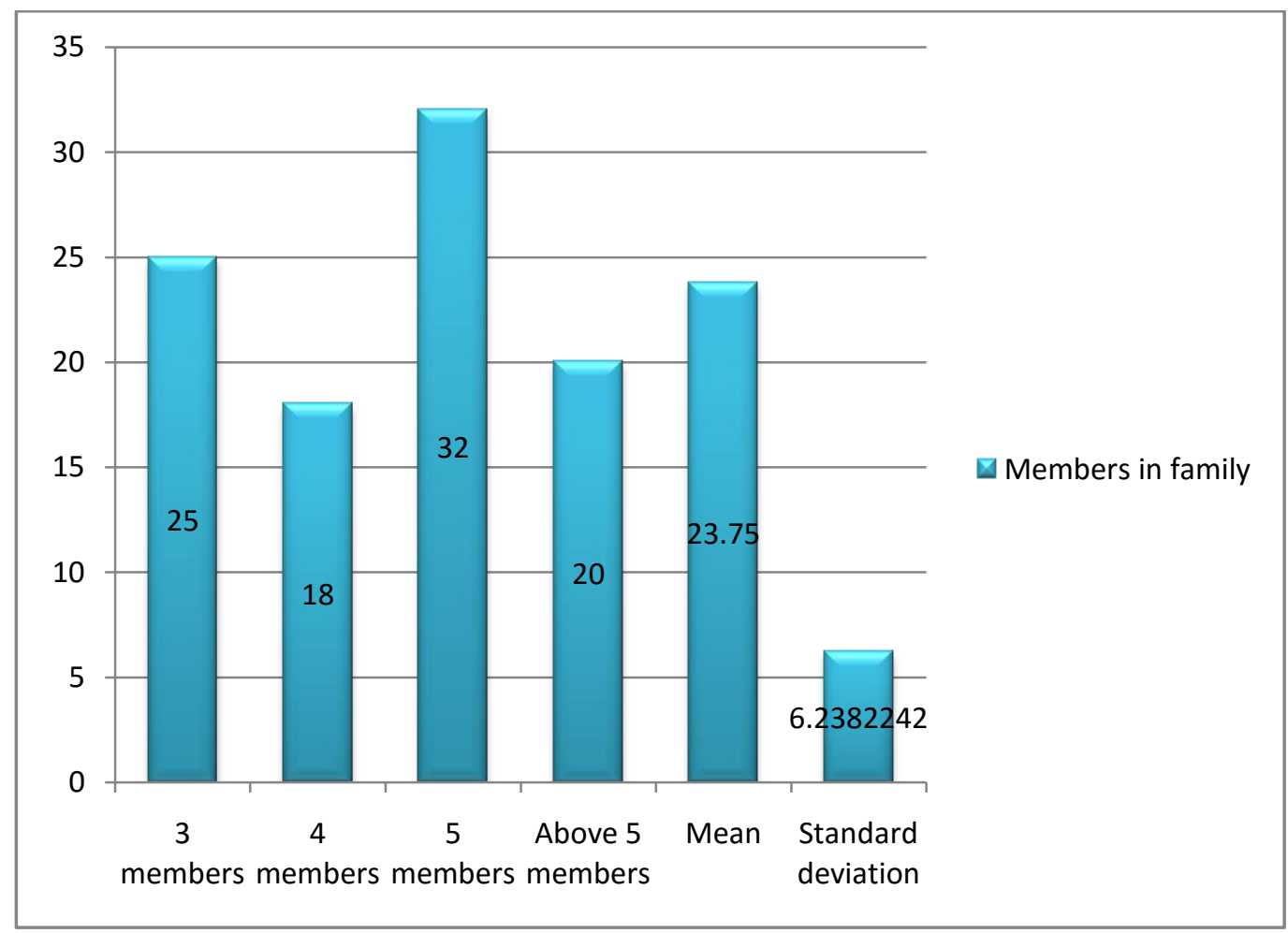

Figure 1.8 Family Members 


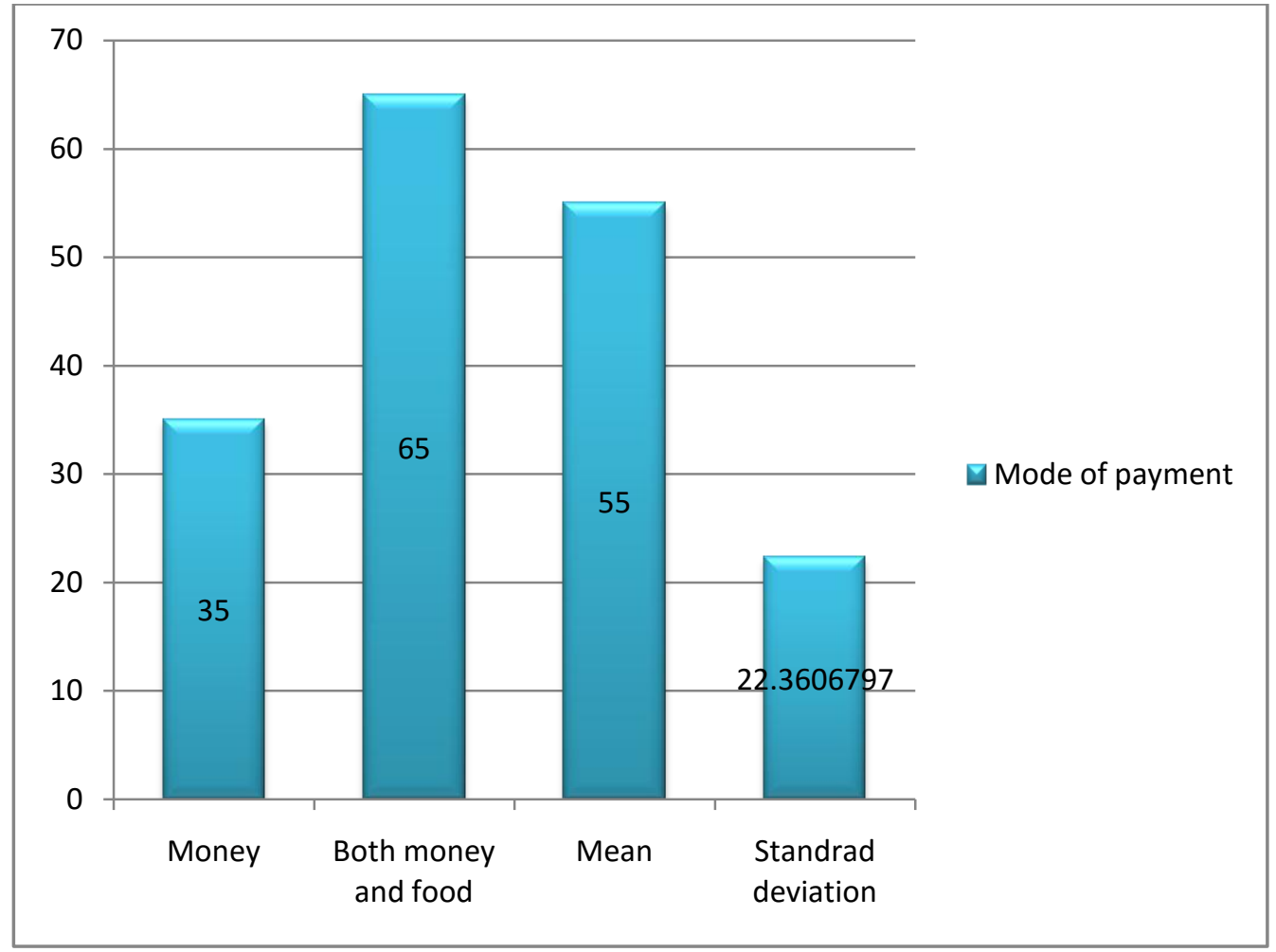

Figure 1.10 Methods of Alms

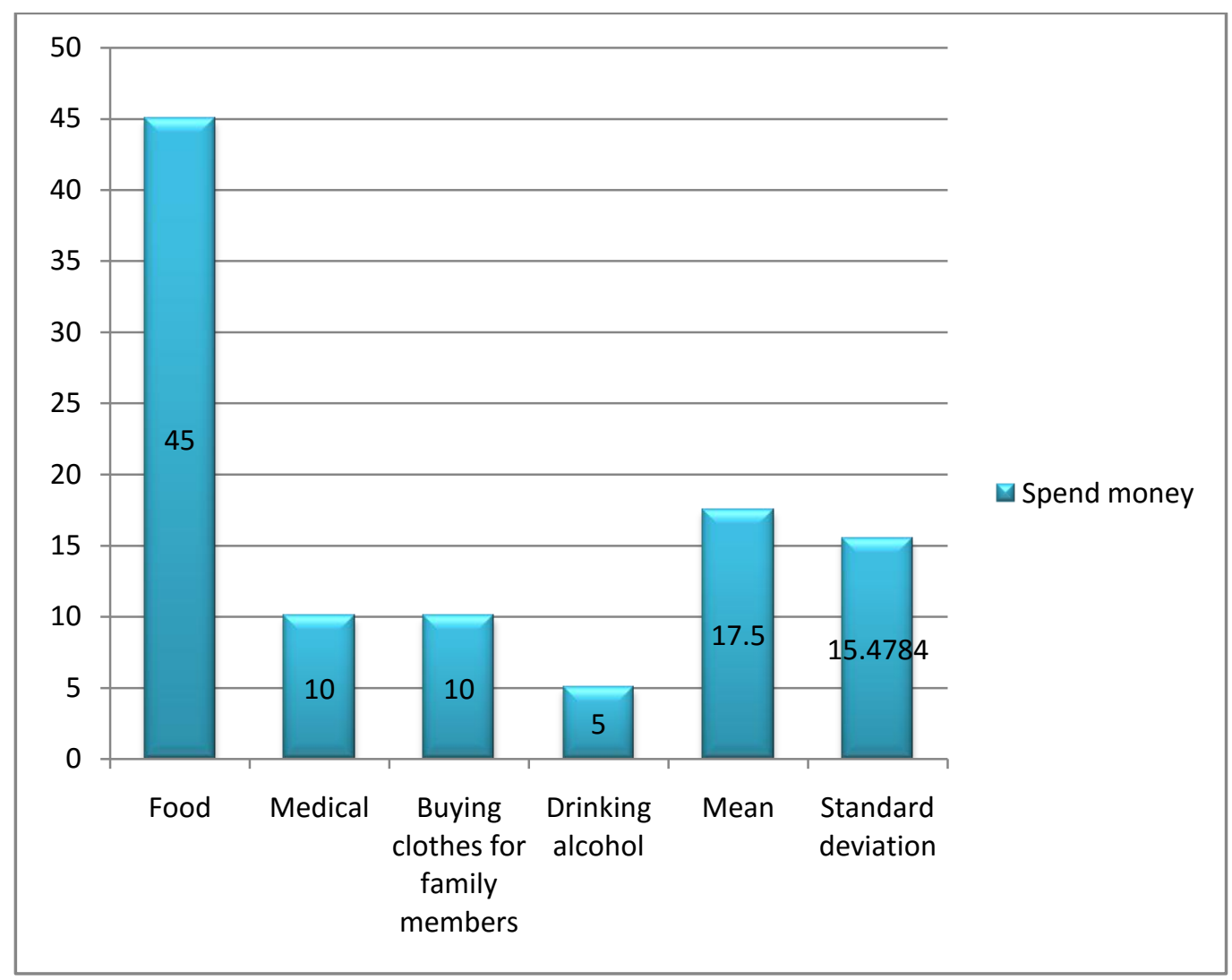

Figure 1.11Use of Alms 


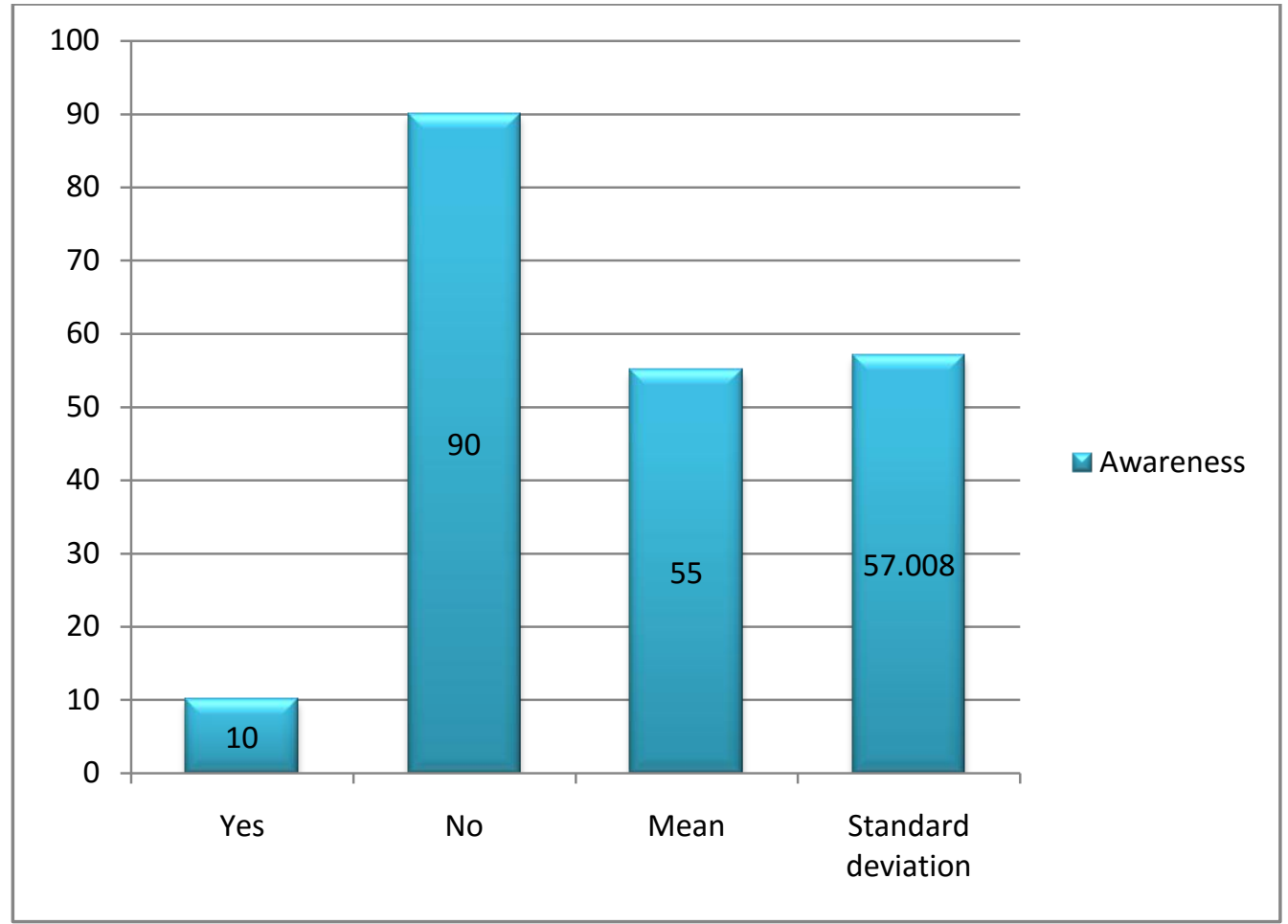

Figure 1.12 Awareness towards Government Schemes

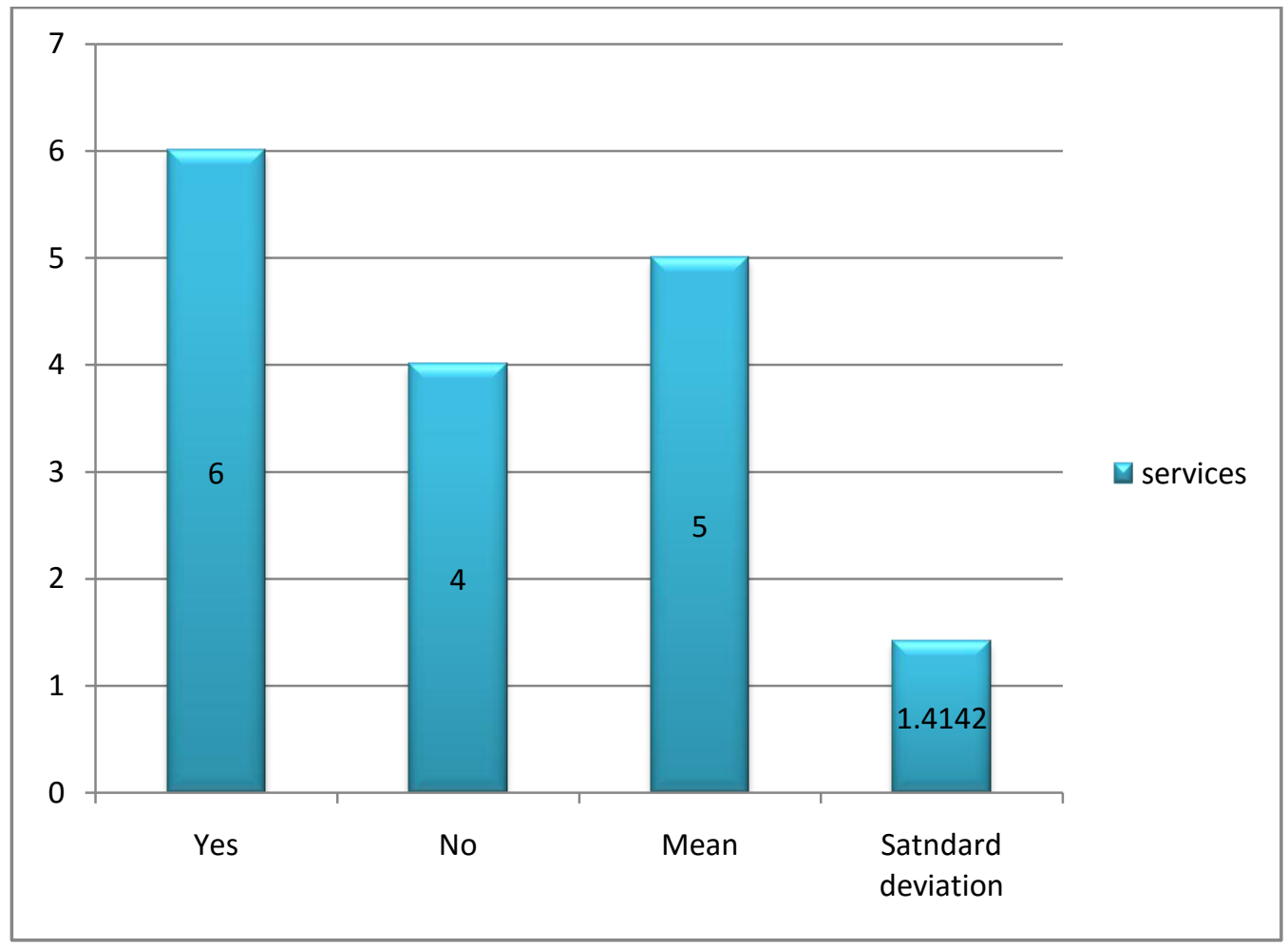

Figure 1.13 Consumption of Government Schemes 


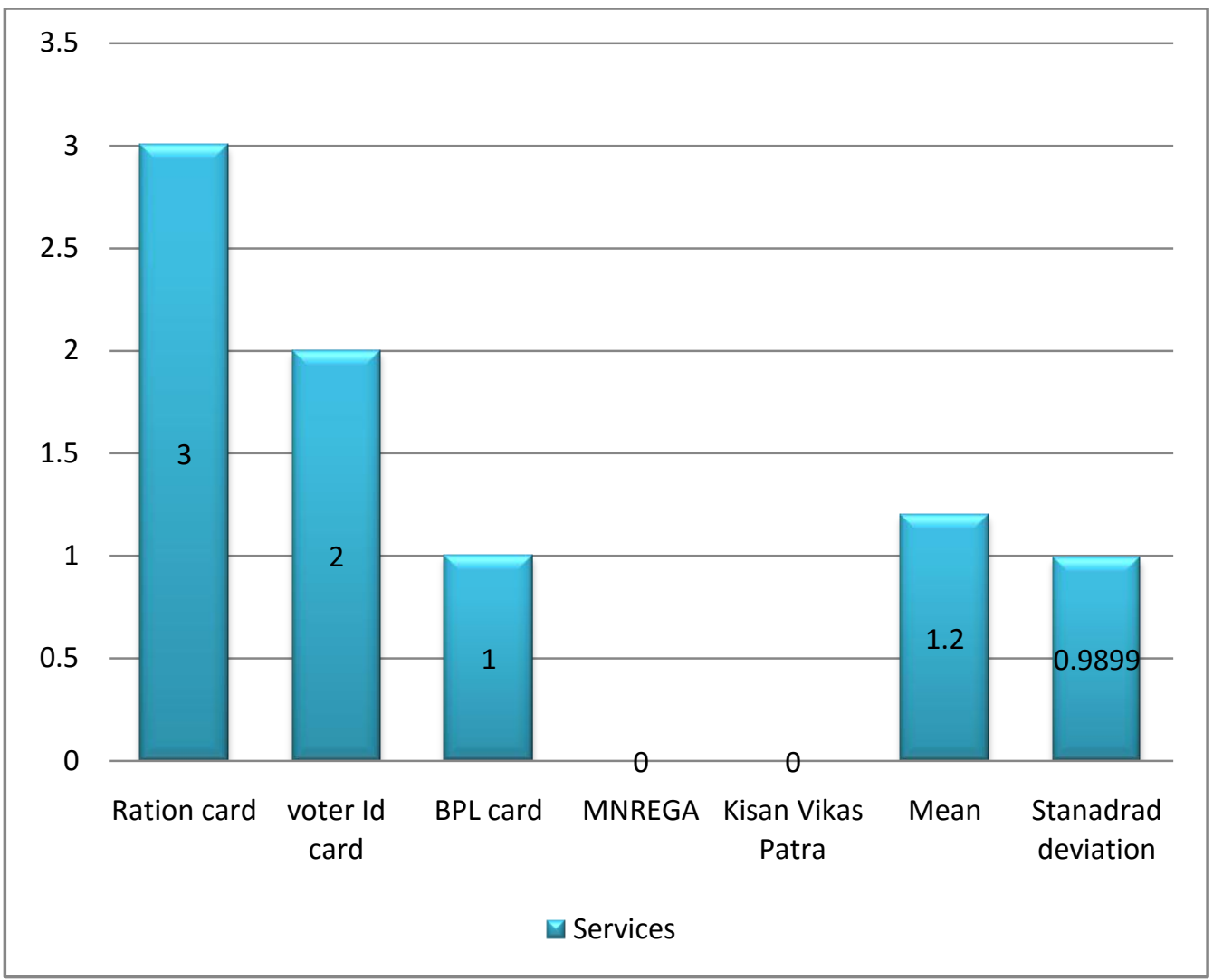

Figure 1.14Types of Services Availed

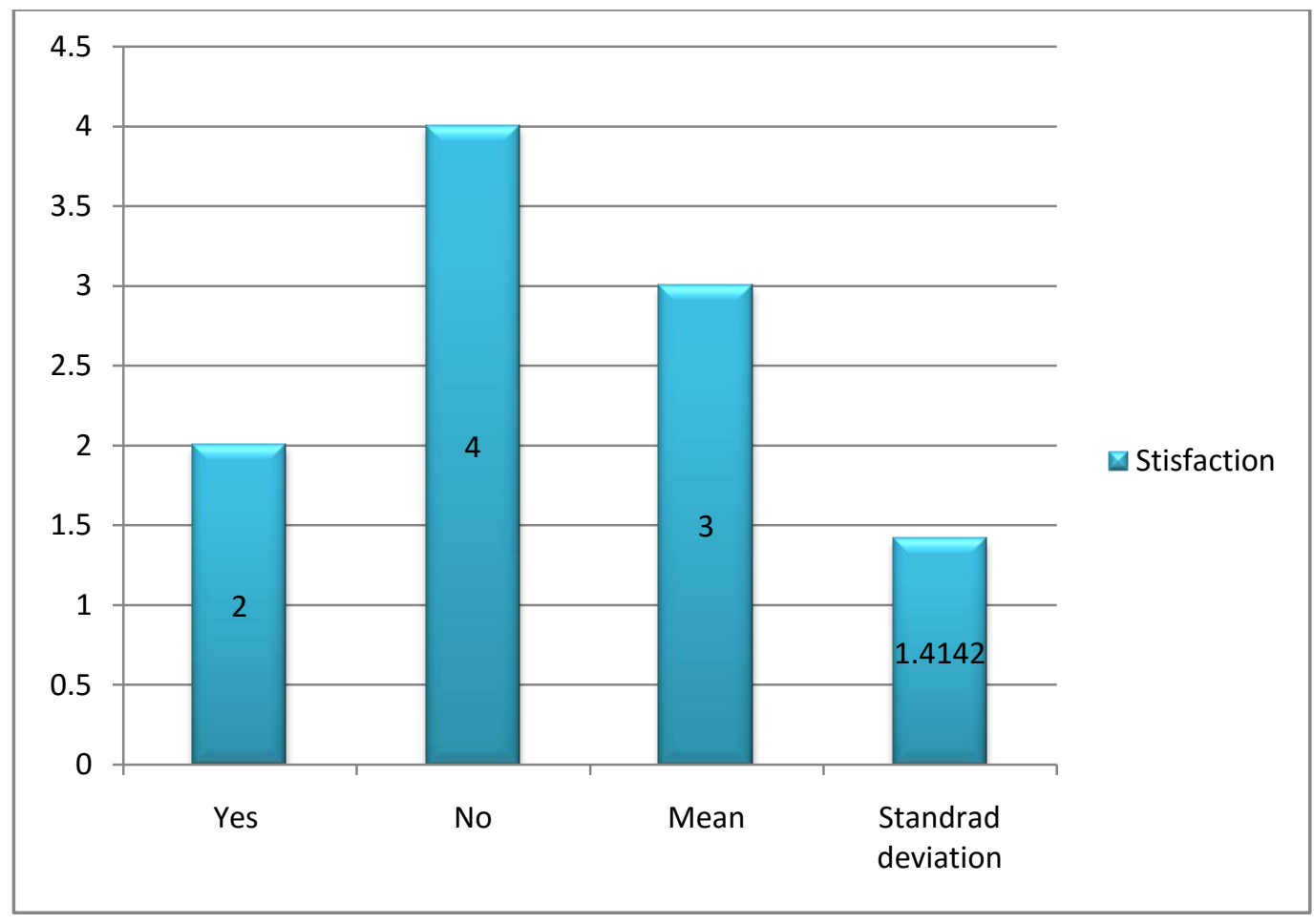

Figure 1.15 Satisfactions Towards Government Schemes Offered 


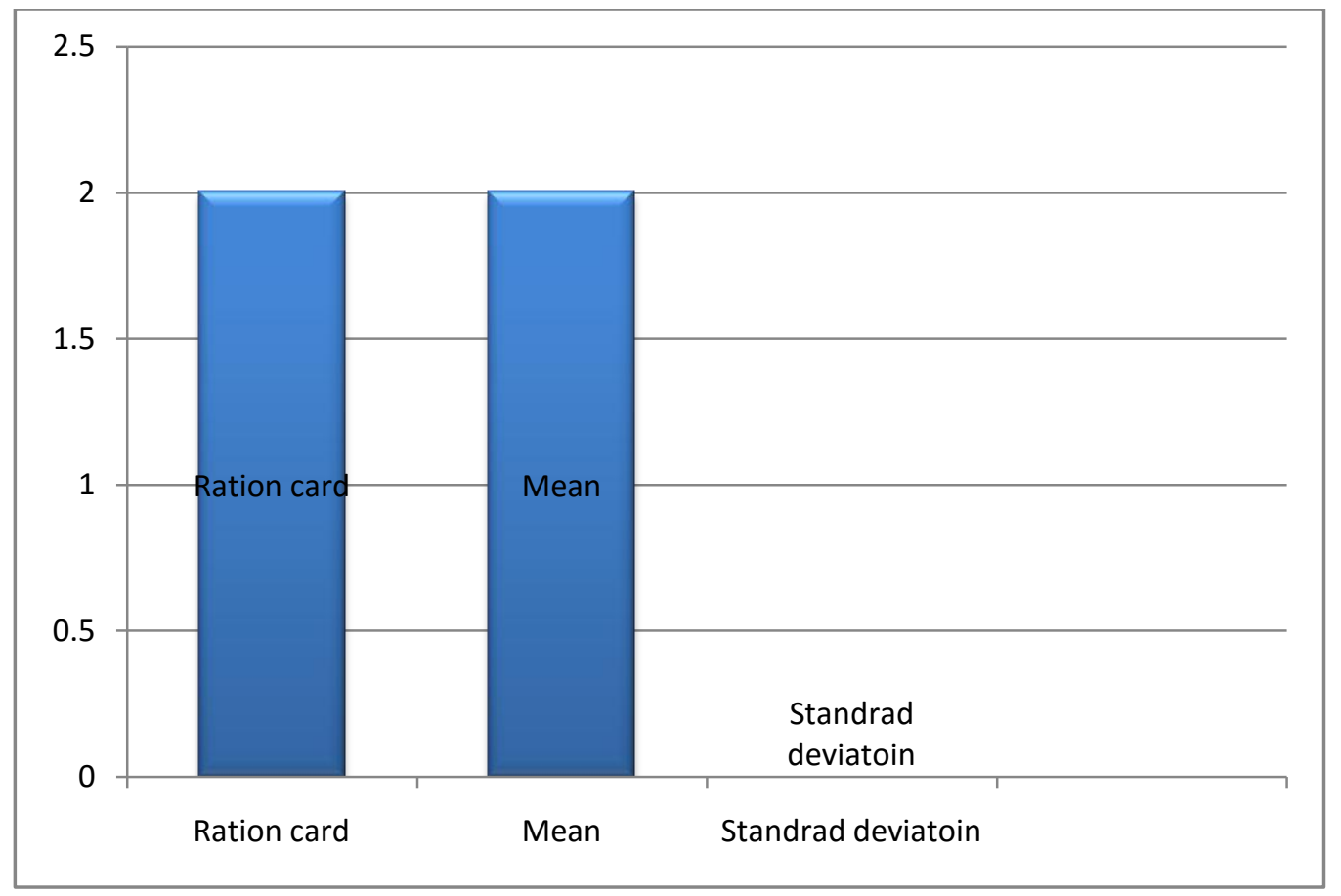

Figure 1.16 Satisfactions towards Government Schemes Offered and Availed 